\title{
Acquired Bernard-Soulier Syndrome

\author{
Evidence for the Role of a 210,000-Molecular Weight Protein in the Interaction \\ of Platelets with von Willebrand Factor
}

Raphael B. Stricker, Dan Wong, Samuel R. Saks, Laurence Corash, and Marc A. Shuman
Cancer Research Institute, Departments of Medicine and Laboratory Medicine, University of California, San Francisco, California 94143

\begin{abstract}
A patient with a lymphoproliferative disorder developed bleeding associated with a prolonged bleeding time and a selective defect of platelet aggregation in response to ristocetin. The patient's purified IgG was shown to inhibit aggregation of washed normal platelets by ristocetin and von Willebrand factor (F VIII:vWF). By Western blotting, it was shown that antibody bound specifically to an antigen of $M_{\mathbf{r}} \mathbf{2 1 0 , 0 0 0}$ present on normal platelets but missing on platelets from patients with congenital BernardSoulier syndrome (BSS). Binding was effected by the $F(\mathbf{a b})_{2}$ portion of the IgG, indicating the presence of an autoantibody rather than an immune complex. These results suggest that the 210,000 $M_{r}$ protein is involved in the interaction of F VIII:vWF with platelets. Furthermore, we have demonstrated the apparent absence of an additional protein on congenital BSS platelets. Heataggregated IgG was also shown to bind to the $210,000-M_{r}$ protein, suggesting that this protein may function as an $\mathrm{Fc}$ receptor on platelets. The relationship of the $210,000-M_{r}$ protein to glycoprotein Ib and the precise role of this protein in the interaction of platelets with F VIII:vWF need to be characterized.
\end{abstract}

\section{Introduction}

The Bernard-Soulier syndrome (BSS) ${ }^{1}$ is a rare autosomal recessive bleeding disorder characterized by moderate to severe thrombocytopenia and abnormally large platelets that have diminished adhesion to the vascular subendothelium (1). Ristocetin-induced binding of von Willebrand factor (F VIII:vWF) to these platelets has been shown to be reduced (2). The molecular basis for these functional abnormalities appears to be deficiency of glycoprotein Ib (GP Ib), a major component of the platelet plasma membrane (3). Bernard-Soulier platelets have

Address reprint requests to Dr. Stricker, 1282-M, Cancer Research Institute, University of California, San Francisco, CA 94143.

Received for publication 18 April 1985 and in revised form 26 June 1985 .

1. Abbreviations used in this paper: BSS, Bernard-Soulier syndrome; $\mathrm{F}$ VIII:Ag, von Willebrand factor antigen; F VIII:C, factor VIII procoagulant activity; F VIII:RCo, ristocetin cofactor; F VIII:vWF, von Willebrand factor; GP Ib, glycoprotein Ib; PAGE, polyacrylamide gel electrophoresis; PAIg, platelet-associated immunoglobulin; TBS, Tris-buffered saline; vWD, von Willebrand disease.

J. Clin. Invest.

(c) The American Society for Clinical Investigation, Inc.

$0021-9738 / 85 / 09 / 1274 / 05 \quad \$ 1.00$

Volume 76, September 1985, 1274-1278 also been shown to be deficient in membrane glycoproteins $\mathrm{V}$ $\left(M_{\mathrm{r}} 82,000\right)$ and IX $\left(M_{\mathrm{r}} 22,000\right)(1)$. The significance of these membrane defects is unclear, however.

The structure of GP Ib appears to be complex. Unreduced GP Ib has been shown by sodium dodecyl sulfate-polyacrylamide gel electrophoresis (SDS-PAGE) to have a molecular weight of 170,000 when labeled with ${ }^{3} \mathrm{H}$ after periodate treatment of platelet membranes (4). In contrast, labeling of GP Ib with ${ }^{125} \mathrm{I}$ after neuraminidase treatment yields a polypeptide of $M_{\mathrm{r}} 150,000$ (5). In addition, Nachman et al. (5) and Kunicki et al. (6) have identified a membrane glycoprotein that copurifies with GP Ib when wheat germ lectin affinity chromatography is employed. This "structural analogue" of GP Ib has a molecular weight of 210,000 by SDS-PAGE $(5,6)$. It has not been further characterized.

We describe a patient with lymphadenopathy and a polyclonal gammopathy of unknown etiology who developed excessive bleeding associated with a prolonged bleeding time and abnormal ristocetin-induced platelet aggregation. A circulating immunoglobulin $\mathrm{G}$ (IgG) that inhibited ristocetin-induced platelet aggregation was shown to bind specifically to the 210,000 $M_{\mathrm{r}}$ protein.

\section{Case report}

The patient is a 35-yr-old heterosexual black male with a previous history of intravenous drug use. In 1976, he developed diffuse lymphadenopathy and was told he had mononucleosis. In 1978, the lymphadenopathy became more prominent. Lymph node biopsy samples in 1978, 1979, and 1980 showed reactive hyperplasia and plasmacytosis without evidence of malignancy. There was no excess bleeding after the biopsy procedures. Past history revealed that the patient had sustained a complex fracture of the left arm in a motorcycle accident and had undergone several tooth extractions without excess bleeding.

In 1983, severe headaches prompted the patient to seek medical attention. A normochromic normocytic anemia with a hemoglobin of $9.5 \mathrm{~g} / \mathrm{dl}$ was found. Serum protein electrophoresis revealed polyclonal hypergammaglobulinemia with $\mathrm{IgG}>8$ $\mathrm{g} / \mathrm{dl}$ (normal $0.5-1.4 \mathrm{~g} / \mathrm{dl}$ ). Circulating immune complexes were not increased. Antinuclear antibody, rheumatoid factor, and serum complement studies were normal, and cryoglobulins were not present. Hepatitis B core antibody was positive but surface antigen was negative. Serum viscosity was elevated at 3.2 (normal 1.5-2.5). The patient's headaches responded to treatment with oxycodone.

In January 1984, the patient underwent a fourth lymph node biopsy that again showed lymphoid hyperplasia and plasmacytosis. A bone marrow biopsy specimen revealed lymphocytosis and normal iron stores. No excess bleeding was noted after these 
procedures. However, in March 1984, a biopsy of the nasal mucosa was done because of chronic rhinitis and sinusitis. This procedure was followed by $3 \mathrm{~d}$ of hemorrhage despite repeated nasal packing. The bleeding time was found to be $>30 \mathrm{~min}$ (normal $<10 \mathrm{~min}$ ). The platelet count was $351,000 / \mu \mathrm{l}$ with a mean platelet volume of $7.5 \mathrm{fl}$ (normal, 7.4-10.4 fl) and normal platelet morphology on peripheral blood smear; tests for disseminated intravascular coagulation were negative (see Table I). The serum IgG was $8.4 \mathrm{~g} / \mathrm{dl}$ and platelet-associated antibody was increased. After six 4-liter plasmaphereses, the serum IgG fell to $2.5 \mathrm{~g} / \mathrm{dl}$. A repeat bleeding time after plasmapheresis was $8 \mathrm{~min}$. When plasmapheresis was discontinued, however, the serum IgG rose to $>10 \mathrm{~g} / \mathrm{dl}$ and the bleeding time prolonged to $>20$ min. Prednisone therapy lowered the $\mathrm{IgG}$ level to $4.5 \mathrm{~g} / \mathrm{dl}$, but severe diabetes mellitus resulted. The prednisone was tapered to $5 \mathrm{mg} /$ day, and the serum IgG has been stable at $5 \mathrm{~g} / \mathrm{dl}$. No further clinical bleeding has occurred on this regimen despite a bleeding time of $20 \mathrm{~min}$.

\section{Methods}

Coagulation tests. Prothrombin time, activated partial thromboplastin time, thrombin time, fibrinogen, fibrin degradation products, factor VIII procoagulant activity (F VIII:C), von Willebrand factor antigen (F VIII: $\mathrm{Ag}$ ), and ristocetin cofactor (F VIII:RCo) were determined by previously described techniques $(7,8)$. The bleeding time was measured by the standard template technique (9). Mean platelet volume was determined in a Coulter $\mathrm{S}+\mathbf{4}$ cell analyzer (Coulter Electronics Inc., Hialeah, FL).

Immunoglobulin and $F(a b)_{2}$ preparation. Blood was obtained in March 1984 prior to plasmapheresis, and IgG was purified from serum by means of Staphylococcus aureus protein A separation (10). Protein

Table I. Laboratory Data of Patient

\begin{tabular}{|c|c|c|}
\hline $\begin{array}{l}\text { Results of } \\
\text { patient }\end{array}$ & Test & Normal results \\
\hline 12.0 & Prothrombin time & $10.5-12.5 \mathrm{~s}$ \\
\hline 28.9 & Partial thromboplastin time & $24-38 \mathrm{~s}$ \\
\hline 28.2 & Thrombin time & $24-35 \mathrm{~s}$ \\
\hline 228 & Fibrinogen & $200-400 \mathrm{mg} / \mathrm{dl}$ \\
\hline 5 & Fibrin degradation products & $<10 \mu \mathrm{g} / \mathrm{ml}$ \\
\hline$>30$ & Bleeding time & $<10 \mathrm{~min}$ \\
\hline 351,000 & Platelet count & $140,000-450,000 / \mu 1$ \\
\hline 7.5 & Mean platelet volume & $7.4-10.4 \mathrm{fl}$ \\
\hline Positive & $\begin{array}{l}\text { Platelet-associated } \\
\text { immunoglobulin }\end{array}$ & Negative \\
\hline $367 \%$ & $\begin{array}{l}\text { Factor VIII activity } \\
\text { (F VII:C) }\end{array}$ & $50-150 \%$ \\
\hline $2.55 \mathrm{U}$ & $\begin{array}{l}\text { Factor VIII antigen } \\
\text { (F VIII:Ag) }\end{array}$ & $0.4-2.31 \mathrm{U}$ \\
\hline \multirow[t]{9}{*}{$270 \%$} & $\begin{array}{l}\text { Factor VIII ristocetin } \\
\text { cofactor (F VIII:RCo) }\end{array}$ & $44-158 \%$ \\
\hline & Platelet aggregation & \\
\hline & Epinephrine & Normal \\
\hline & Collagen & Normal \\
\hline & ADP & Normal \\
\hline & Gamma-thrombin & Normal \\
\hline & Calcium ionophore & Normal \\
\hline & Arachidonic acid & Normal \\
\hline & Ristocetin & Absent \\
\hline
\end{tabular}

concentration was measured by the Bio-Rad modification (Bio-Rad Laboratories, Richmond, CA) of the technique of Lowry et al. (11). Aggregated IgG was prepared by heating control immunoglobulin at $63^{\circ} \mathrm{C}$ for $10 \mathrm{~min}$. The $\mathrm{IgG}$ was stored at $-20^{\circ} \mathrm{C}$ until use.

$\mathrm{F}(\mathrm{ab})_{2}$ fragments were prepared by a modification of the method of Madsen and Rodkey (12): $10 \mathrm{mg}$ of IgG in phosphate-buffered saline (PBS) was dialyzed against $0.1 \mathrm{M}$ sodium acetate, $\mathrm{pH} 4.5$, for $3 \mathrm{~h}$ at $4^{\circ} \mathrm{C}$. Freshly prepared pepsin (Sigma Chemical Co., St. Louis, MO) suspended in the same buffer at $4 \mathrm{mg} / \mathrm{ml}$ was added to give a final concentration of $2 \%(w t / w t)$ pepsin per milligram total globulin. The solution was then incubated overnight at $37^{\circ} \mathrm{C}$ and dialyzed against PBS, pH 7.4, for $8 \mathrm{~h}$. The digestion products were incubated with protein $\mathrm{A}$ bacterial adsorbent (Miles Scientific Div., Miles Laboratories, Naperville, IL) for $30 \mathrm{~min}$ at $4^{\circ} \mathrm{C}$. The beads were centrifuged and the supernatant free of IgG and $F(c)$ fragments was again analyzed for protein concentration. The yield of $F(a b)_{2}$ by this technique was $50-80 \%$. Samples of $\operatorname{IgG}$ and $F(a b)_{2}$ were also subjected to SDS-PAGE and demonstrated the absence of residual IgG in the $\mathrm{F}(\mathrm{ab})_{2}$ preparations. The $\mathrm{F}(\mathrm{ab})_{2}$ was stored at $-20^{\circ} \mathrm{C}$ until use.

Platelet aggregation. Platelet aggregation studies were performed in a Payton dual channel aggregometer (Payton Scientific Inc., Buffalo, NY) with the following reagents: ADP ( 4 and $8 \mu \mathrm{M}$ ), epinephrine (10 $\mu \mathrm{M})$, collagen $(0.26 \mathrm{mg} / \mathrm{ml})$, gamma thrombin $(2 \mu \mathrm{g} / \mathrm{ml})$, arachidonic acid $(500 \mu \mathrm{g} / \mathrm{ml})$, calcium ionophore A23187 $(13 \mu \mathrm{g} / \mathrm{ml})$, and ristocetin (1.5 and $3 \mathrm{mg} / \mathrm{ml})$. Initial studies were carried out using the patient's platelet-rich plasma. Subsequent aggregation studies were performed on washed human platelets, using the following procedure. Utilizing a discontinuous 10-20\% Stractan gradient and isopycnic centrifugation (13), platelets were isolated from the whole blood of normal subjects. The platelets were then washed in 6 vol of calcium-free Tyrode's buffer ( $\mathrm{pH}$ 7.4), centrifuged at $400 \mathrm{~g}$ for $15 \mathrm{~min}$ and resuspended in either heterologous platelet-poor plasma or Tyrode's buffer with calcium $(1.8 \mathrm{mM})$ and magnesium $(0.49 \mathrm{mM})$ to a platelet concentration of $200,000 / \mu \mathrm{l}$. Recovery of the total platelet population was $\geq 85 \%$. These platelets were responsive to all aggregating agents including ADP (with fibrinogen added when suspended in Tyrode's buffer), collagen, thrombin, arachidonic acid, calcium ionophore A23187, and ristocetin.

Studies of inhibition of platelet aggregation were performed as follows. Washed control platelets were incubated with $(a)$ patient or control plasma at room temperature, or $(b) \operatorname{IgG}$ or $\mathrm{F}(\mathrm{ab})_{2}$ in Tyrode's buffer at $4^{\circ} \mathrm{C}$. Control IgG was obtained from Kabi, Stockholm, Sweden. Calcium and magnesium were added just before the aggregation study. Platelet aggregation was performed with the addition of cryoprecipitate (diluted 1:100) as a source of von Willebrand factor and ristocetin (Thromboscreen, Pacific Hemostasis, Bakersfield, CA) at a final concentration of 1.5 and $3 \mathrm{mg} / \mathrm{ml}$.

Platelet antibody. Platelet-associated immunoglobulin (PAIg) was detected by means of a fluorescence-activated flow cytometric assay. Platelets were isolated from acid citrate dextrose-anticoagulated whole blood by differential centrifugation. The platelets were then washed once in PBS glucose and resuspended in $1 \%$ ammonium oxalate to lyse contaminating erythrocytes. After three washes in calcium-free Tyrode's buffer, the platelets were fixed with $1 \%$ paraformaldehyde and reacted with biotin-conjugated goat anti-human $F(a b)_{2}$ directed against IgG, IgM, and IgA. The cells were then incubated with an avidin-fluorescein isothiocyanate label, washed, and passed through a Becton Dickinson flow cytometer (Becton Dickinson \& Co., Sunnyvale, CA), and mean fluorescence was determined. A normal range was defined, and each sample was compared to its own negative control using a goat anti-rabbit $\mathrm{F}(\mathrm{ab})_{2}$ conjugated to biotin. PAIg was expressed as mean platelet fluorescence on a logarithmic scale. A positive sample was greater than two standard deviations above its negative control.

Western blotting. Washed O-positive human platelets were isolated from normal donors as described above. After the final wash in calciumfree Tyrode's buffer, the platelets were resuspended in PBS at $10^{9} / \mathrm{ml}$ $(1.2 \mathrm{mg} / \mathrm{ml})$ and solubilized in sample buffer containing $2 \%$ SDS, $2 \mathrm{mM}$ EDTA, $0.05 \mathrm{M}$ imidazole, $15 \%$ glycerol, $1 \%$ (vol/vol) aprotinin, pH 7.0. Patient platelets were isolated and solubilized in an identical manner, 
as were platelets from a patient with BSS, except that the BSS platelets were used in a concentration of $6 \times 10^{8} / \mathrm{ml}(3.6 \mathrm{mg} / \mathrm{ml})$. The BSS platelets were generously provided by Dr. Margaret Johnson of the Medical Center of Delaware, Newark, DE.

$50 \mu$ l of platelets was electrophoresed in 5\% SDS-polyacrylamide gels according to the method of Laemmli (14). The samples were then transferred to nitrocellulose by the method of Towbin et al. (15) at $30 \mathrm{~V}$ for $16 \mathrm{~h}$. Blocking was performed using 5\% gelatin in Tris-buffered saline (TBS) for $1 \mathrm{~h}$ at $37^{\circ} \mathrm{C}$, after which the nitrocellulose was incubated with test serum, IgG, or F(ab) ${ }_{2}$ diluted 1:100 in TBS-1\% gelatin for $2 \mathrm{~h}$. After washing in TBS, the samples were incubated with a 1:500 dilution of biotin-conjugated goat $\mathrm{F}(\mathrm{ab})_{2}$ anti-human immunoglobulin (Tago Inc., Burlingame, CA) for $1 \mathrm{~h}$. After further washing in TBS, the nitrocellulose was incubated with avidin-conjugated peroxidase (Cappel Laboratories, Malvern, PA) diluted 1:500 in TBS 1\% gelatin for $1 \mathrm{~h}$. Color development was carried out using 4-chloronaphthol as substrate (16). The nitrocellulose was then dried and photographed. High molecular weight standards (Bio-Rad Laboratories, Hayward, CA, and Pharmacia Fine Chemicals, Piscataway, NJ) were simultaneously electrophoresed and transferred with the samples. These were stained with $0.05 \%$ amido black and served as molecular weight markers for the blots.

\section{Results}

The results of coagulation studies and routine platelet aggregometry are shown in Table I. All tests of coagulation were normal except for the bleeding time, which was markedly prolonged. Platelet count and platelet size were normal at all times. F VIII: C, F VIII:RCo, and F VIII:Ag were all higher than control, effectively excluding an inhibitor of F VIII protein or a defect in function of the patient's F VIII complex. Agonist-induced aggregation of the patient's platelet-rich plasma was normal except for the response to ristocetin, which was diminished even at twice the usual concentration. In addition, PAIg measured by the fluorescence-activated cell sorter technique was shown to be increased. This finding suggested the presence of a platelet-associated inhibitor of ristocetin-induced aggregation and prompted studies of the patient's IgG.

Results of aggregation with washed platelets in the presence of patient or control plasma, IgG and $\mathrm{F}(\mathrm{ab})_{2}$ are shown in Figs. 1 and 2. In Fig. 1, the patient's plasma inhibited ristocetin-induced aggregation of control platelets by $80 \%$. Similarly, the patient's IgG suspended in Tyrode's buffer at a concentration of $2 \mathrm{mg} / \mathrm{ml}$ inhibited ristocetin-induced aggregation by $70 \%$, compared to an equivalent concentration of control IgG. In Fig. 2 , the patient's $F(a b)_{2}$ in a concentration of $5 \mathrm{mg} / \mathrm{ml}$ also inhibited aggregation to the same extent. No inhibitory effect was seen when ADP or collagen were used as aggregating agents (data not shown). Thus the patient's IgG fraction specifically inhibited aggregation of control platelets by ristocetin.

Fig. 3 shows the binding of serum antibody to platelet antigens immobilized on nitrocellulose. The patient's antibody bound to a protein of $M_{\mathrm{r}} 210,000$ that was present on both heterologous and autologous platelets (lane $A$ ). In contrast, binding to BSS platelets did not occur (lane $B$ ). Antibody binding to normal platelets was demonstrated with as little as $10 \mu \mathrm{g}$ of control platelet protein. In contrast, binding to BSS platelets could not be demonstrated even when $360 \mu \mathrm{g}$ of platelet protein was used (data not shown). Thus control platelets contain at least 36 times more GP 210 than BSS platelets. Serum from two other patients with antibody-associated platelet dysfunction failed to bind to the $M_{\mathrm{r}} 210,000$ protein (lane $E$ ). These patients' platelets displayed normal aggregation responses to ristocetin

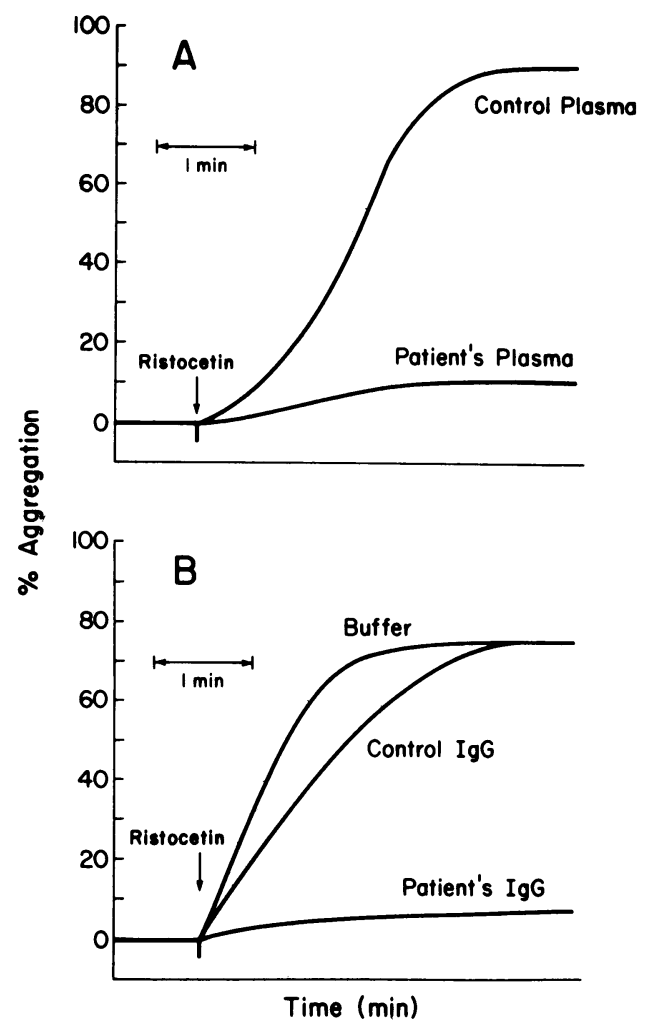

Figure 1. Washed platelet aggregation in response to ristocetin. Platelets were incubated with plasma for $30 \mathrm{~min}$ at room temperature or with $\mathrm{IgG}$ for $16 \mathrm{~h}$ at $4^{\circ} \mathrm{C}$ before addition of ristocetin $(1.5 \mathrm{mg} / \mathrm{ml}) .(A)$ Patient plasma inhibited aggregation by $80 \%$ compared with control plasma. (B) Patient IgG $(2 \mathrm{mg} / \mathrm{ml})$ inhibited aggregation by $70 \%$ compared with control $\operatorname{lgG}(2 \mathrm{mg} / \mathrm{ml})$. Curves are drawn from original aggregometry tracings.

but decreased reactivity to ADP and collagen. Finally, heat-aggregated control IgG was also shown to bind to the $M_{\mathrm{r}} 210,000$ antigen (lane $C$ ), suggesting the possibility of interaction with an $F(c)$ receptor. However, the patient's $F(a b)_{2}$ also bound to this antigen (lane $D$ ), indicating that an autoantibody rather than an immune complex was responsible for binding.

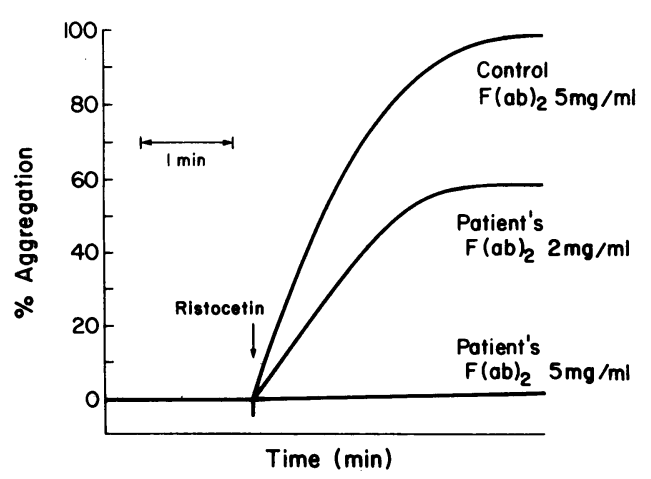

Figure 2. Washed platelet aggregation in response to ristocetin. Platelets were incubated with $\mathrm{F}(\mathrm{ab})_{2}$ for $3 \mathrm{~h}$ at $4^{\circ} \mathrm{C}$ prior to addition of ristocetin. Patient $\mathrm{F}(\mathrm{ab})_{2}(5 \mathrm{mg} / \mathrm{ml})$ inhibited aggregation by $90 \%$ compared with control $F(a b)_{2}(5 \mathrm{mg} / \mathrm{ml})$, whereas a lower concentration of patient $\mathrm{F}(\mathrm{ab})_{2}(2 \mathrm{mg} / \mathrm{ml})$ inhibited aggregation by $40 \%$. 


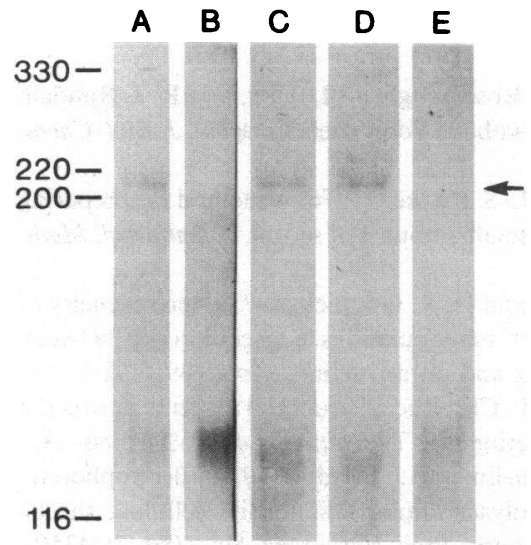

Figure 3. Western blot showing antibody binding to platelet antigen. Solubilized platelets were electrophoresed in 5\% SDS-polyacrylamide gels, transferred to nitrocellulose, and incubated with antibody samples. Antibody binding was detected using a biotin-avidin-peroxidase system. Lane $A$, control platelets incubated with patient serum; lane $B$, BSS platelets incubated with patient serum; lane $C$, control platelets incubated with heat-aggregated IgG; lane $D$, control platelets incubated with patient $\mathrm{F}(\mathrm{ab})_{2}$; lane $E$, control platelets incubated with control serum. Note band of $M_{\mathrm{r}} 210,000$ (arrow) detected on control platelets but not on BSS platelets. Band at $M_{\mathrm{r}} 150,000$ represents IgG in the platelet preparations.

\section{Discussion}

This patient presented with lymphadenopathy and hypergammaglobulinemia of unknown etiology without evidence of a congenital bleeding disorder. He developed profuse hemorrhage after a minor surgical procedure and was found to have a prolonged bleeding time and an isolated defect of ristocetin-induced platelet aggregation. Further studies revealed elevated PAIg and binding of serum IgG to a $210,000-M_{\mathrm{r}}$ platelet protein.

The mechanism of ristocetin-induced platelet aggregation has been presumed to involve binding of F VIII:vWF to the GP Ib complex (17). The effect of ristocetin is thought to be related to its net positive charge (18). Because both the F VIII:vWF molecule and the platelet surface are electronegatively charged, they are mutually repulsive. Ristocetin interaction with the GP Ib complex decreases the net negative charge on the platelet surface, allowing F VIII:vWF to bind (18). Alteration of the charge on the F VIII:vWF molecule, such as in some forms of acquired von Willebrand disease (vWD) (17), or lack of binding of F VIII:vWF to the absent GP Ib complex, such as in BSS (19), results in decreased ristocetin-induced platelet aggregation.

Our patient differs from reported cases of acquired VWD in several important respects. Although the bleeding history, bleeding time, and defective ristocetin-induced platelet aggregation are consistent with acquired VWD, all functional and immunologic components of the patient's F VIII complex are intact. In addition, the inhibitory effect of IgG on platelet aggregation and the demonstration of serum antibody binding to autologous platelets strongly suggest acquired platelet dysfunction. To our knowledge, this type of antibody-induced dysfunction in the presence of a normal platelet count has not previously been reported. Degos et al. (20) described a polytransfused BSS patient with alloantibody against a component of GP Ib, but this antibody did not react with the patient's own platelets since they lacked the glycoprotein. Quinidine-dependent antiplatelet antibody appears to be directed against the GP Ib complex (4, 6 ), but this antibody generally results in accelerated platelet destruction and has not been shown to cause platelet dysfunction. Recently, Woods et al. (21) identified autoantibody to GP Ib in sera from 3 of 106 patients with chronic immune thrombocytopenic purpura. Like the patients with quinidine-dependent platelet antibodies, however, these patients had severe thrombocytopenia, and platelet function studies were not performed.

The target $210,000-M_{\mathrm{r}}$ antigen identified in our patient appears to be functionally related to GP Ib. Evidence for this derives from three observations. First, the $210,000-M_{\mathrm{r}}$ protein copurifies with GP Ib on wheat germ affinity chromatography (unpublished observation). Second, like GP Ib, the $210,000-M_{\mathrm{r}}$ protein is present in normal platelets but not on BSS platelets. This is the first demonstration of deficiency of this $210,000-M_{\mathrm{r}}$ glycoprotein in BSS platelets. Third, both the $210,000-M_{\mathrm{r}}$ protein and GP Ib appear to be necessary for ristocetin-induced platelet aggregation. The specific component of GP Ib to which F VIII:vWF binds has not been defined. Thus it is possible that the $210,000-M_{\mathrm{r}}$ glycoprotein that we have found to be missing from BSS platelets serves as a receptor for F VIII:vWF. Alternatively, if the 210,000$M_{\mathrm{r}}$ molecule and the $170,000-M_{\mathrm{r}}$ glycoprotein identified as GP Ib are present as a noncovalent complex or are located in proximity on the platelet plasma membrane, the antibody against the $210,000-M_{\mathrm{r}}$ protein could sterically hinder interaction of $\mathrm{F}$ VIII:vWF with the $170,000-M_{\mathrm{r}}$ glycoprotein.

The nature of antibody binding to the target antigen in our patient appears to be that of an autoantibody directed against the $210,000-M_{\mathrm{r}}$ glycoprotein rather than an immune complex demonstrating $\mathrm{F}(\mathrm{c})$ binding at this site. Moore et al. (22) have shown that immune complexes or $F(c)$ fragments may interfere with ristocetin-induced platelet aggregation, implicating GP Ib as a receptor for both F VIII:vWF and the F(c) portion of IgG. Recently, however, Pfueller et al. (23) have shown that chymotrypsin-treated platelets have normal $F(c)$ receptor expression even though they fail to aggregate in response to ristocetin, suggesting that the $F(c)$ receptor may involve platelet membrane sites other than GP Ib. In preliminary experiments (Stricker, R. B., and M. A. Shuman, manuscript in preparation), we have found that chymotrypsin-treated platelets are deficient in $\mathrm{GP} \mathrm{Ib}$ but retain the $210,000-M_{\mathrm{r}}$ glycoprotein. These platelets bind heataggregated IgG but not antibody against GP Ib. Thus the $210,000-M_{\mathrm{r}}$ protein appears to function as an $\mathrm{F}(\mathrm{c})$ receptor on normal platelets. Beardsley et al. (24) noted binding of radiolabeled goat and human IgG aggregates to a similar $M_{\mathrm{r}}$ protein. The structural relationship between this protein and GP Ib requires further study.

In summary, we have described a patient with acquired platelet dysfunction that resembles congenital BSS. This disorder is manifested by clinical bleeding, a prolonged bleeding time, normal F VIII function, and an IgG inhibitor of ristocetin-induced platelet aggregation due to $\mathrm{F}(\mathrm{ab})_{2}$ binding to a platelet protein of $M_{\mathrm{r}} 210,000$. In contrast to the congenital syndrome, platelet size and morphology appear to be normal in this disease. We propose the term "acquired Bernard-Soulier syndrome" to distinguish this entity from acquired vWD, and to emphasize the platelet-dependent nature of the abnormality. In addition, our findings suggest that the $210,000-M_{\mathrm{r}}$ glycoprotein missing in BSS may serve as a receptor for F VIII:vWF. 


\section{Acknowledgments}

The authors thank Dr. Margaret Johnson of the Medical Center of Delaware, Newark, DE, for providing Bernard Soulier platelets. We also thank Fay Weimer and Margaret Rheinschmidt for technical assistance.

This work was supported by grants 1F32 HL 06871-01 CLN and HL 21403 from the National Heart, Lung and Blood Institute. Dr. Shuman is the recipient of a Research Career Development Award, 1 K04 HL-00802, from the National Institutes of Health.

\section{References}

1. Berndt, M. C., C. Gregory, B. H. Chong, H. Zola, and P. A. Castaldi. 1983. Additional glycoprotein defects in Bernard-Soulier's syndrome: confirmation of genetic basis by parental analysis. Blood. 62:800-807.

2. Nurden, A. T., and J. P. Caen. 1979. The different glycoprotein abnormalities in thrombasthenic and Bernard-Soulier platelets. Semin. Hematol. 16:234-250.

3. Grottum, K. A., and N. O. Solum. 1969. Congenital thrombocytopenia with giant platelets: a defect in the platelet membrane. $\mathrm{Br}$. $J$. Haematol. 16:277-290.

4. Chong, B. H., M. C. Berndt, J. Koutts, and P. A. Castaldi. 1983. Quinidine-induced thrombocytopenia and leukopenia: demonstration and characterization of distinct antiplatelet and antileukocyte antibodies. Blood. 62:1218-1223.

5. Nachman, R. L., T. Kinoshita, and B. Ferris. 1979. Structural analysis of human platelet membrane glycoprotein I complex. Proc. Natl. Acad. Sci. USA. 76:2952-2954.

6. Kunicki, T. J., N. Russell, A. T. Nurden, R. H. Aster, and J. P. Caen. 1981. Further studies of the human platelet receptor for quinineand quinidine-dependent antibodies. J. Immunol. 126:398-402.

7. Dombrose, F. A., C. C. Barnes, L. Gaynor, and R. C. Elston. 1982. A lyophilized, multi-assay human reference plasma for coagulation factors: evidence for stability of Factors I, II, V, and VII through XII. Am. J. Clin. Pathol. 77:32-45.

8. Allain, J. P., H. A. Cooper, R. H. Wagner, and K. M. Brinkhous. 1975. Platelets fixed with paraformaldehyde: a new reagent for assay of von Willebrand factor and platelet aggregating factor. J. Lab. Clin. Med. 85:318-328.

9. Babson, S. R., and A. L. Babson. 1978. Development and evaluation of a disposable device for performing simultaneous duplicate bleeding time determinations. Am. J. Clin. Pathol. 70:406-408.

10. Kessler, S. W. 1981. Use of protein A bearing Staphylococci for the immunoprecipitation and isolation of antigens from cells. Methods Enzymol. 73:442-459.

11. Lowry, O. H., N. J. Rosebrough, A. L. Farr, and R. J. Randall. 1951. Protein measurement with the Folin phenol reagent. J. Biol. Chem. 139:265-275.

12. Madsen, L. H., and L. S. Rodkey. 1976. A method for preparing IgG $\mathrm{F}(\mathrm{ab})_{2}$ fragments using small amounts of serum. J. Immunol. Methods. 9:355-361.

13. Corash, L., H. Tan, and H. R. Gralnick. 1977. Heterogeneity of human whole blood platelet subpopulations. I. Relationship between buoyant density, cell volume and ultrastructure. Blood. 49:71-87.

14. Laemmli, U. K. 1970. Cleavage of structural proteins during the assembly of the head of bacteriophage T4. Nature (Lond.). 227:680-685.

15. Towbin, H., T. Staehelin, and J. Gordon. 1979. Electrophoretic transfer of proteins from polyacrylamide gels to nitrocellulose sheets: procedure and some applications. Proc. Natl. Acad. Sci. USA. 76:43504354.

16. Hawkes, R. 1982. Identification of concanavalin A-binding proteins after sodium dodecyl sulfate-gel electrophoresis and protein blotting. Anal. Biochem. 123:143-146.

17. Zimmerman, T. S., Z. M. Ruggeri, and C. A. Fulcher. 1983. Factor VIII/von Willebrand factor. Prog. Hematol. 13:279-309.

18. Coller, B. S., and H. R. Gralnick. 1977. Studies on the mechanism of ristocetin-induced platelet agglutination. J. Clin. Invest. 60:302-312.

19. Moake, J. L., J. D. Olson, J. H. Troll, S. S. Tang, T. Funicella, and D. M. Peterson. 1980. Binding of radioiodinated human von Willebrand factor to Bernard-Soulier, thrombasthenic and von Willebrand's disease platelets. Thromb. Res. 19:21-27.

20. Degos, L., G. Tobelem, and P. Lethielieux. 1977. A molecular defect in platelets from patients with Bernard-Soulier syndrome. Blood. 50:899-903.

21. Woods, V. L., Y. Kurata, R. R. Montgomery, P. Tani, D. Mason, E. H. Oh, and R. McMillan. 1984. Autoantibodies against platelet glycoprotein Ib in patients with chronic immune thrombocytopenic purpura. Blood. 64:156-160.

22. Moore, A., G. D. Ross, and R. L. Nachman. 1978. Interaction of platelet membrane receptors with von Willebrand factor, ristocetin, and the Fc region of immunoglobulin G. J. Clin. Invest. 62:1053-1060.

23. Pfueller, S. L., N. Kerlero de Rosbo, and R. A. Bilston. 1984. Platelets deficient in glycoprotein I have normal Fc receptor expression. Br. J. Haematol. 56:607-615.

24. Beardsley, D. S., J. E. Spiegel, M. M. Jacobs, R. I. Handin, and S. E. Lux. 1984. Platelet membrane glycoprotein IIIa contains target antigens that bind anti-platelet antibodies in immune thrombocytopenias. J. Clin. Invest. 74:1701-1707. 